\title{
Correction to: Genetic composition and evolution of the prevalent Mycobacterium tuberculosis lineages 2 and 4 in the Chinese and Zhejiang Province populations
}

Beibei Wu ${ }^{1 \dagger}$, Wenlong Zhu ${ }^{2 \dagger}$, Yue Wang ${ }^{2}$, Qi Wang ${ }^{2}$, Lin Zhou' ${ }^{1}$ Zhengwei Liu', Lijun Bi ${ }^{3}$, Mathema Barun ${ }^{4}$, Barry N. Kreiswirth" ${ }^{5}$ Liang Chen ${ }^{5}$, Songhua Chen ${ }^{1}$, Xiaomeng Wang ${ }^{1 *}$ and Weibing Wang ${ }^{2,6^{*}}$ (D)

\section{Correction to: Cell Biosci (2021) 11:162}

https://doi.org/10.1186/s13578-021-00673-7

In the version of this article initially published, the Additional file 3 was incorrect. The correct file includes five figures (namely, Figure S1 to S5) and those five figures should be inserted as ESM file separately. The error has been corrected in the HTML versions of the article.

All the changes requested are implemented in this correction and the original article [1] has been corrected.

\section{Supplementary Information}

The online version contains supplementary material available at https://doi. org/10.1186/s13578-021-00692-4.

Additional file 3: Figure S1. Changes of the distribution of Mycobacterium tuberculosis sub-lineages in Zhejiang Province (a) and five regions (b east, d west, e south, $\mathbf{f}$ north, $\mathbf{g}$ middle) from 1998 to 2013. $\mathbf{c}$ is the map of Zhejiang Province and the five regions.

Additional file 4: Figure S2. Phylogenetic tree of 197 Mycobacterium tuberculosis strains in China.

The original article can be found online at https://doi.org/10.1186/s13578 021-00673-7.

\section{*Correspondence: xmwang@cdc.zj.cn; wwb@fudan.edu.cn}

${ }^{\dagger}$ Beibei Wu and Wenlong Zhu contributed equally to this work

${ }^{1}$ Zhejiang Center for Disease Control and Prevention, Institute of Tuberculosis Control, 3399 Binsheng Road, Binjiang District, Hangzhou 310051, Zhejiang, China

2 Department of Epidemiology, School of Public Health, Fudan University, 138 Yi Xue Yuan Road, Shanghai 200032, China

Full list of author information is available at the end of the article
Additional file 5: Figure S3. Phylogenetic tree of 48 Mycobacterium tuberculosis strains in Zhejiang Province.

Additional file 6: Figure S4. Pairwise ratios of rates of nonsynonymous to synonymous substitutions (dN/dS) in sub-lineages in lineage $2(\mathbf{a})$ and lineage 4 (b) for epitopes and non-epitope regions of T cell antigens. Wilcoxon rank-sum test was used to evaluated the differences of dN/ dS between epitope and non-epitope regions of T cell antigens in each sub-lineage.

Additional file 7: Figure S5. Frequency distribution of the number of epitopes with nonsynonymous variants. A total of $491 \mathrm{~T}$ cell epitopes were included in the analysis. The number above each bar corresponds to the epitope count. a lineage 2 , b lineage 4 .

\section{Author details}

'Zhejiang Center for Disease Control and Prevention, Institute of Tuberculosis Control, 3399 Binsheng Road, Binjiang District, Hangzhou 310051, Zhejiang, China. ${ }^{2}$ Department of Epidemiology, School of Public Health, Fudan University, 138 Yi Xue Yuan Road, Shanghai 200032, China. ${ }^{3}$ Key Laboratory of RNA Biology, Institute of Biophysics, Chinese Academy of Sciences, Beijing, China. ${ }^{4}$ Department of Epidemiology, Mailman School of Public Health, Columbia University, New York, USA. ${ }^{5}$ Hackensack-Meridian Health Center for Discovery and Innovation, Nutley, NJ 07110, USA. 'Department of Epidemiology, Key Laboratory of Public Health Safety of Ministry of Education, Fudan University, 138 Yi Xue Yuan Road, Shanghai 200032, China.

Accepted: 24 September 2021

Published online: 21 October 2021

\section{Reference}

1. Wu B, Zhu W, Wang Y, Wang Q, Zhou L, Liu Z, Bi L, Barun M, Kreiswirth BN, Chen L, Chen S, Wang Z, Wang W. Genetic composition and evolution of permits use, sharing, adaptation, distribution and reproduction in any medium or format, as long as you give appropriate credit to the original author(s) and the source, provide a link to the Creative Commons licence, and indicate if changes were made. The images or other third party material in this article are included in the article's Creative Commons licence, unless indicated otherwise in a credit line to the material. If material is not included in the article's Creative Commons licence and your intended use is not permitted by statutory regulation or exceeds the permitted use, you will need to obtain permission directly from the copyright holder. To view a copy of this licence, visit http://creativecommons.org/licenses/by/4.0/. The Creative Commons Public Domain Dedication waiver (http://creativeco mmons.org/publicdomain/zero/1.0/) applies to the data made available in this article, unless otherwise stated in a credit line to the data. 
the prevalent Mycobacterium tuberculosis lineages 2 and 4 in the Chinese and Zhejiang Province populations. Cell Biosci. 2021;11:162. https://doi. org/10.1186/s13578-021-00673-7.

\section{Publisher's Note}

Springer Nature remains neutral with regard to jurisdictional claims in published maps and institutional affiliations.
Ready to submit your research? Choose BMC and benefit from:

- fast, convenient online submission

- thorough peer review by experienced researchers in your field

- rapid publication on acceptance

- support for research data, including large and complex data types

- gold Open Access which fosters wider collaboration and increased citations

- maximum visibility for your research: over $100 \mathrm{M}$ website views per year

At BMC, research is always in progress.

Learn more biomedcentral.com/submissions 